\begin{tabular}{lccc}
\hline Oropharyngeal dysfunction & $\begin{array}{c}\text { Present } \\
(\mathrm{n}=29)\end{array}$ & $\begin{array}{c}\text { absent } \\
(\mathrm{n}=5)\end{array}$ & p-values $\left(\mathrm{x}^{2}\right.$-test $)$ \\
\hline dcSSc & 8 & 0 & 0,027 \\
IcSSc & 22 & 4 & 0,027 \\
disease duration (mean) & $12,7 \mathrm{y}$ & $12 \mathrm{y}$ & 0,462 \\
mRSS $<$ r & 9 & 2 & 0,322 \\
mRSS $>4$ & 20 & 3 & 0,322 \\
Raynauds syndrom & 29 & 5 & 0,673 \\
digital ulcers & 19 & 2 & 0,812 \\
lung fibrosis & 11 & 2 & 0,596 \\
eosophageal dilatation & 15 & 2 & 0,566 \\
eosophageal dysmotility & 19 & 0 & 0,015 \\
Gl-involvement & 23 & 1 & 0,007 \\
\hline
\end{tabular}

Conclusion: Logopedic assessment revealed a high incidence of oropharyngeal dysfunction in our cohort of SSc patients. Oropharyngeal dysfunction was not associated with disease duration, skin- or lung-involvement or dcSSc/lcSSc differentiation. A logopedic training program seems to be of benefit for this currently not pharmacologically treatable problem.

References:

[1] Schmeiser T, Saar P, Jin D, Noethe M, Müller A, Soydan N, et al. Profile of gastrointestinal involvement in patients with systemic sclerosis. Rheumatol Int 2012;32:2471-8. doi:10.1007/s00296-011-1988-6.

[2] Boeckxstaens GE, Bartelsman JFWM, Lauwers L, Tytgat GNJ. Treatment of GI dysmotility in scleroderma with the new enterokinetic agent prucalopride. Am J Gastroenterol 2002;97:194-7. doi:10.1016/S0002-9270(01)03958-2.

[3] Mercado U, Arroyo de Anda R, Avendaño L, Araiza-Casillas R, Avendaño-Reyes M. Metoclopramide response in patients with early diffuse systemic sclerosis. Effects on esophageal motility abnormalities. Clin Exp Rheumatol 2005;23:685-8.

Disclosure of Interests: Miriam Wirths: None declared, Ole Hudowenz: None declared, Ulrike Hoffmann: None declared, Ulf Müller-Ladner Speakers bureau: Biogen, Uwe Lange: None declared, Philipp Klemm Consultant of: Lilly, Medac DOI: 10.1136/annrheumdis-2020-eular.3467

\section{THU0351 MUSCLE INVOLVEMENT IN PATIENTS WITH SYSTEMIC SCLEROSIS AND ANTI-PM/SCL+ ANTIBODIES IS ASSOCIATED WITH CARDIAC AND PULMONARY INVOLVEMENT. ANALYSIS OF THE MULTICENTRE EUSTAR COHORT.}

M. G. Lazzaroni ${ }^{1}$, S. Zingarelli ${ }^{1}$, P. Airò ${ }^{1}$, Y. Allanore ${ }^{2}$, O. Distler ${ }^{3}$ on behalf of EUSTAR co-authors. ${ }^{1}$ ASST Spedali Civili of Brescia, University of Brescia, Brescia, Italy; ${ }^{2}$ University Paris Descartes and Cochin Hospital, Paris, France; ${ }^{3}$ University Hospital Zurich, Zurich, Switzerland

Background: Anti-PM/Scl antibodies positivity has been associated with frequent skeletal muscle involvement in patients with Systemic Sclerosis (SSc) in different studies, including the EUSTAR cohort (1). Moreover, although myositis has been previously associated with heart involvement in SSc patients (2), this issue has never been explored among anti-PM/Scl+ patients.

Objectives: To evaluate the cardiac involvement in anti-PM/Scl patients with SSc in the large multicentre EUSTAR database, with focus on the subgroup of patients with muscle involvement.

Methods: Patients from the EUSTAR database were included when the item anti-PM/Scl was fulfilled in at least one visit.

Results: Anti-PM/Scl status was available in 7,353 SSc patients from EUSTAR database: 295 were anti-PM/Scl+. After exclusion of 151 patients with multiple autoantibody positivity, 144 anti-PM/Scl + patients were compared with 7,058 anti-PM/Scl- patients. Among them, 3,120 (44.2\%) were positive for ACA, 2,361 (33.5\%) for anti-Topo I and 274 (3.88\%) for anti-RNAP3.

Regarding the specific cardiac outcomes, in the anti-PM/Scl+ as compared to the anti-PM/Scl- group, a decreased rate of elevated SPAP at ECHO was recorded (12.8\% vs $25.0 \%$, p:0.001), while no differences were observed in the frequency of conduction blocks (26.2\% vs $23.7 \%$, p:0.526), abnormal diastolic function (33.9\% vs $36.4 \%$, p:0.582), pericardial effusion (10.2\% vs $10.9 \%, \mathrm{p}: 1.000)$ and LVEF $\leq 50 \%$ (4.76\% vs $6.11 \%$, p:0.818). In multivariate analysis, adjusted for age at disease onset, sex, and disease duration, the negative association of anti-PM/ $\mathrm{Scl}$ with elevated SPAP was not confirmed (p:0.061).

When comparing anti-PM/Scl+ patients with $(n=47)$ and without $(n=87)$ CK elevation, the former group had a higher frequency of conduction blocks $(43.2 \%$ vs $17.5 \%$, p:0.005; OR $95 \% \mathrm{Cl} 3.47,1.51-7.97)$ and left ventricular dysfunction, both diastolic (45.6\% vs 27.2\%, p:0.050; OR 95\% Cl 2.25, 1.05-4.81) and systolic (LVEF $\leq 50 \% 13.3 \%$ vs $0 \%$, p:0.018; OR 95\% Cl 16.8, 0.87-324). Moreover, anti-PM/Scl+ patients with CK elevation had significantly increased rate of lung fibrosis on HRCT (p:0.045), intestinal symptoms (p:0.017), joint contractures (p:0.045) and tendon friction rubs (p:0.034)

Conclusion: In the largest series of anti-PM/Scl positive SSc patients so far reported, muscle involvement in anti-PM/Scl+ patients (defined as increased serum $\mathrm{CK}$ ) seems to represent a marker of a more severe disease phenotype, including a higher frequency of cardio-pulmonary involvement.

References:

[1] Lazzaroni MG, et al. Ann Rheum Dis 2018. 77 (2), 421-2.

[2] Follansbee WP, et al. Am Heart J 1993. 125: 194-203.

Acknowledgments: Authors would like to thank the patients' association GILS (Gruppo Italiano Lotta Sclerodermia) for the grant that supported the project Disclosure of Interests: Maria Grazia Lazzaroni: None declared, Stefania Zingarelli: None declared, Paolo Airò: None declared, Yannick Allanore Grant/ research support from: BMS, Inventiva, Roche, Sanofi, Consultant of: Actelion Bayer AG, BMS, BI, Oliver Distler Grant/research support from: Grants/Research support from Actelion, Bayer, Boehringer Ingelheim, Competitive Drug Development International Ltd. and Mitsubishi Tanabe; he also holds the issued Patent on mir-29 for the treatment of systemic sclerosis (US8247389, EP2331143). Consultant of: Consultancy fees from Actelion, Acceleron Pharma, AnaMar Bayer, Baecon Discovery, Blade Therapeutics, Boehringer, CSL Behring, Catenion, ChemomAb, Curzion Pharmaceuticals, Ergonex, Galapagos NV, GSK Glenmark Pharmaceuticals, Inventiva, Italfarmaco, iQvia, medac, Medscape, Mitsubishi Tanabe Pharma, MSD, Roche, Sanofi and UCB, Speakers bureau: Speaker fees from Actelion, Bayer, Boehringer Ingelheim, Medscape, Pfizer and Roche

DOI: 10.1136/annrheumdis-2020-eular.3525

\section{THU0352 DIAGNOSTIC PERFORMANCES OF HAND ULTRASOUND PARAMETERS AND THEIR IMPACT ON THE 2013 ACR/EULAR CLASSIFICATION CRITERIA FOR SYSTEMIC SCLEROSIS.}

M. De Saint Riquier ${ }^{1}$, A. Ballerie ${ }^{2}$, F. Robin $^{3}$, N. Belhomme ${ }^{4}$, C. Cazalets ${ }^{4}$, C. Droitcourt ${ }^{5}$, A. Perdriger ${ }^{1}$, C. M. Yelnik ${ }^{6}$, E. Hachulla ${ }^{7}$, V. Sobanski ${ }^{7}$, P. Jégo ${ }^{2}$, G. Coiffier ${ }^{8}$, A. Lescoat ${ }^{9} .{ }^{1}$ Rheumatology Dept Rennes University Hospital, 35203, Rennes, France., Rennes, France; ${ }^{2}$ Univ Rennes, CHU Rennes, Inserm, EHESP, Irset (Institut de recherche en santé, environnement et travail) - UMR_S 1085, F-35000 Rennes, France, Rennes, France; ${ }^{3}$ Department of Rheumatology, $\mathrm{CHU}$ de Rennes, ${ }^{16}$, Boulevard de Bulgarie, 35200 Rennes, France; Inserm NuMeCan UMR 1274, CIMIAD, University of Rennes, 35000 Rennes, France, Rennes, France; ${ }^{4} \mathrm{CHU}$ Rennes, Internal Medicine and Clinical Immunology Dpt F-35000 Rennes, France, Rennes, France; ${ }^{5}$ Dermatology Dept Rennes University Hospital, 35203, Rennes, France., Rennes, France; ${ }^{6}$ University Lille, INSERM U 995, CHU Lille, Centre de Référence des Maladies Autoimmunes Systémiques Rares du Nord et Nord-Ouest de France, Lille, France., Lille, France; ${ }^{7}$ University Lille, INSERM U 995, CHU Lille, Centre de Référence des Maladies Autoimmunes Systémiques Rares du Nord et Nord-Ouest de France, Lille, France., Lille, France; ${ }^{8} \mathrm{CHU}$ Rennes, University of Rennes, INSERM U 1241, Rennes, France., Rennes, France; ${ }^{9}$ Univ Rennes, CHU Rennes, Inserm, EHESP, Irset (Institut de recherche en santé, environnement et travail) - UMR_S 1085, F-35000 Rennes, France, Rennes, France

Background: Recent studies have highlighted that ultrasound (US) examination could offer a better assessment of hand manifestations of systemic sclerosis (SSc). Indeed, US allows a simultaneous evaluation of vascular, fibrotic and inflammatory hand features of the disease. Power Doppler US can especially explore macrovascular involvement characterized by an obliteration of digital arteries or ulnar arteries. UInar artery occlusion (UAO) is especially frequent in SSc patients and could be a relevant marker of the severity of SSc-associated vasculopathy. Among other hand manifestations of SSc, US evaluation can notably explore tenosynovial involvement such as fibrotic tenosynovitis (TS), which is considered to be SSc-specific.

Objectives: This study aims to assess the diagnostic performances of these hand US parameters for the diagnosis of SSc.

Methods: 244 patients with suspected SSc were consecutively included. They all had US evaluation assessing the presence of fibrotic TS and UAO. The final diagnosis of SSc was based on the evaluation of an expert, independently from US results and from any pre-established classification criteria

Results: 166 patients were finally diagnosed as SSc. 62 SSc and 8 non-SSc patients had UAO (uni or bilateral) $(p=0.001) .23$ SSc patients and 1 non-SSc patient had US fibrotic TS $(\mathrm{p}=0.007)$. A US SSc-pattern (presence of UAO and/or fibrotic TS) was reported in 73 SSc patients and 9 non-SSc patients $(p<0.001)$. UAO had an area under ROC curve (AUC) for the diagnosis of SSc of $0.618(95 \% \mathrm{Cl} 0.539-0.697)$; with $\mathrm{Se}=0.373(0.304-0.449)$ and $\mathrm{spe}=0.862$ 
(0.751-0.928). The presence of a US fibrotic TS had an AUC of 0.561 (0.480$0.643)$; with $\mathrm{Se}=0.139(0.094-0.199)$ and $\mathrm{spe}=0.983(0.909-0.997)$. The US-SSc pattern had a AUC of 0.641 (0.563-0.695), with $\mathrm{Se}=0.440$ (0.367$0.516)$ and spe $=0.845(0.731-0.916)$. When used as a diagnostic tool, the original 2013 classification criteria had an AUC of $0.982(0.969-0.996)$ with $\mathrm{Se}=$ $0.946(0.900-0.971)$ and spe $=0.931$ (0.836-0.973). Including UAO and fibrotic TS in this classification had few impact (AUC of $0.979(0.962-0.996)$ with $\mathrm{Se}=$ $0.940(0.893-0.967)$ and and spe $=0.931(0.836-0.973))$ but allows the substitution of some items (such as capillaroscopy) by US parameters with similar performances for diagnosis.

Conclusion: The use of hand US parameters may help to refine the diagnostic strategy of SSc and their inclusion in addition with the items of the ACR/EULAR classification could be discussed.

Disclosure of Interests: Marine de Saint Riquier: None declared, Alice Ballerie: None declared, François ROBIN: None declared, Nicolas Belhomme: None declared, Claire Cazalets: None declared, Catherine Droitcourt: None declared, Aleth Perdriger: None declared, Cécile Marie Yelnik: None declared, Eric Hachulla Speakers bureau: speaking fees from Actelion Pharmaceuticals, GlaxoSmithKline, and Bayer outside of the current study, Vincent Sobanski: None declared, Patrick Jégo: None declared, Guillaume Coiffier: None declared, Alain LESCOAT: None declared

DOI: 10.1136/annrheumdis-2020-eular.5621

\section{THU0353 ENDOCAN AND CIRCULATING PROGENITOR CELLS IN SYSTEMIC SCLEROSIS: ASSOCIATION WITH PULMONARY HYPERTENSION}

A. Lo Gullo ${ }^{1}$, D. Sinicropi ${ }^{2}$, M. Cinquegrani ${ }^{2}$, F. Savarino ${ }^{2}$, C. Giuffrida ${ }^{1}$, G. Squadrito', G. Mandraffino' ${ }^{2}{ }^{1}$ I.R.C.C.S. Centro Neurolesi Bonino Pulejo P.O Piemonte, Messina, Italy; ${ }^{2}$ A.O.U. Policlinico "Gaetano Martino", Messina, Italy

Background: Systemic sclerosis (SSc) is characterized by early vascular involvement and by varying degrees of fibrosis in skin, lungs, and other tissues. Vascular manifestations include Raynaud's phenomenon, digital ulcers, and pulmonary hypertension (PAH). The prevalence of PAH is $7.85-13 \%$ in SSc and it is the second most common cause of mortality in SSc. Circulating CD34+ cell number is associated to cardiovascular health status in several chronic conditions, including inflammatory disease. CD34+ cell number was found inconstantly reduced in SSc. Endocan is a proteoglycan expressed by endothelial cells likely interacting with white blood cells, recently suggested as a marker of vascular stress.

Objectives: to evaluate CD34+ cell number and endocan as a markers od cardiovascular involvement in SSc.

Methods: Standard transthoracic echocardiography, Rodnan skin score were performed. Vitamin D levels, CD34+ cell number, markers of inflammation, red blood cells distribution width (RDW) and Endocan plasma levels were also determined.

Results: 37 female SSc patients (11 diffuse/26 limited) and 35 matched healthy controls $(\mathrm{HC})$ were enrolled. CD34+ cell count was lower as compared to controls $(2.3 \pm 0.73$ vs $2.9 \pm 0.6 ; p<0.001)$, CRP and ESR were significantly higher in SSc patients than controls. Vitamin D3 was lower in SSc patients with respect to controls ( $18 \pm 4.5$ vs $27.26 \pm 10.98 ; p<0.001$ ), Rodnan skin score was $28.89 \pm 10.24$. Endocan was two times greater than controls and serum endocan levels were higher in patients with diffuse Ssc as compared with limited ones. We found no correlation between Endocan and: Rodnan skin score, ESR, fibrinogen; we found a trend of correlation between Endocan and Vitamin D levels $(r=-0.315)$, RDW ( $r=0.310)$, CRP $(r=0.310)$, but statistical significance was not reached likely due to the small sample size. We found an association of PAPs with Endocan levels $(r h o=0.442, p<0.01)$ and $C D 34+$ count $(-0.349, p<0.05$. A significant correlation was also found between Endocan and CD34+ cell number (rho= $-0.605, \mathrm{p}<0.01$ ).

Conclusion: In our study population, we found a significant correlation between CD34+ cell number and Endocan plasma levels and PAPs; Endocan and CD34+ progenitor cells might be suggested as potential marker of pulmonary arterial hypertension in SSc patients.

References:

[1] Lo Gullo et al. Atherosclerosis 2018

Disclosure of Interests: Alberto Lo Gullo Speakers bureau: bayer, Davide Sinicropi: None declared, Mara Cinquegrani: None declared, Francesca Savarino: None declared, Clemente Giuffrida: None declared, Giovanni Squadrito: None declared, Giuseppe Mandraffino: None declared

DOI: 10.1136/annrheumdis-2020-eular.5532

\section{THU0354 \\ CHARACTERIZATION OF ANTI-MYOSITIS ANTIBODY RELATED MYOPATHIES. DESCRIPTIVE STUDY IN A MULTICENTRIC COHORT.}

S. López Salguero ${ }^{1}$, M. Andres ${ }^{2}$, P. Vela-Casasempere ${ }^{2}$, A. Esteban Rodriguez $^{2}$, M. P. Martínez-Vidal ${ }^{3}$, J. A. Bernal ${ }^{4}$, A. Alvarez de Cienfuegos ${ }^{5}$, F. Sivera ${ }^{6} .{ }^{1}$ Hospital Universitario de Torrevieja, Alicante, Spain; ${ }^{2}$ Hospital General Universitario de Alicante, Alicante, Spain; ${ }^{3}$ Hospital Universitario San Juan de Alicante, Alicante, Spain; ${ }^{4}$ Hospital Marina Baixa, Villajoyosa, Spain;

${ }^{5}$ Hospital Vega Baja, Orihuela, Spain; ${ }^{6}$ Hospital Universitario de Elda, Elda, Spain

Background: Idiopathic inflammatory myopathies (IIM) are a group of rare diseases consisting on immune-mediated muscle damage. About 40 to $60 \%$ show specific-myositis antibodies; aditionally, $20-40 \%$ can show myositis-related (non-specific) antibodies. The profile of antibodies can help to divide patients into subgroups with more homogeneous clinical characteristics and prognosis.

Objectives: This study characterizes patients with IIM with specific or related anti-myositis antibodies, in five hospitals in the Alicante health area.

Methods: This is an observational study, carried out in five hospitals with a reference population of 1.083 .463 people. Patients with positive anti-myositis antibodies between October 2015 and May 2018 were selected from the database of the Clinical Laboratory of the University Hospital of Alicante. We considered the following antiboides: anti-myositis specific antibodies (anti-TIF1y, anti-MDA5, anti-Mi-2, anti-PmScl75, anti-PMScl100, anti-NXP2, anti-SRP), anti-synthetase antibodies (anti-PL7, anti-PL12, anti-Jo1, anti-OJ), myositis-related antibodies (anti-Ro52, anti-Ku). Clinical records were examined, identifying those patients with a diagnosis of IIM acording to their clinician, rheumatologist. Epidemiological and clinical data were obtained.

Results: 291 patients with positive anti-myositis antibodies were identified. Among them, 40 patients had a diagnosis of IIM. Median age was 59.5 (IQR $41.5,70)$ years and $68 \%$ were women. Within the subgroups, the most frequent diagnosis were dermatomyositis $(n=22 ; 55 \%)$ and polimyositis $(n=9 ; 22 \%)$. The most common antibody detected was anti-TIF-y among specific antibodies, and anti-Jo-1 among the anti-synthetase antibodies. The most common extramuscular feature was skin involvement. The presence of interstitial lung disease was reported in about one third of patients, being UIP the most commong pattern. Regarding treatment, the use of steroids was generalized; methotrexate was the most used inmunosupresant agent. Eight patients had a cancer related myopathy.

\begin{tabular}{|c|c|c|c|c|c|}
\hline & $\mathrm{DM}(\mathrm{N}=22)$ & PM $(n=9)$ & DMJ (N=3) & $\begin{array}{l}\text { IMNM } \\
(n=1)\end{array}$ & AS $(n=5)$ \\
\hline $\begin{array}{l}\text { Age, median } \\
\text { (IQR) }\end{array}$ & $65,5(46,76)$ & $57(34,66)$ & $15,7(14,18)$ & $83(-)$ & $61(56,64)$ \\
\hline Female $n(\%)$ & $15(68,2)$ & $6(66,6)$ & $2(66,6)$ & $1(100)$ & $3(60)$ \\
\hline $\begin{array}{l}\text { Muscular feat. } \\
\mathrm{n}(\%)\end{array}$ & $16(77,7)$ & $9(100)$ & $1(33,3)$ & $1(100)$ & $5(100)$ \\
\hline ILD n(\%) & $1(4,5)$ & $3(33,3)$ & 0 & 0 & $5(100)$ \\
\hline Disfagia $n(\%)$ & $3(13,6)$ & $1(11,1)$ & 0 & 0 & 0 \\
\hline Skin feat $n(\%)$ & $17(77,3)$ & 0 & $2(66,6)$ & 0 & $1(20)$ \\
\hline arthritis $\mathrm{n}(\%)$ & $1(4,5)$ & 0 & $2(66,6)$ & 0 & $4(80)$ \\
\hline Raynaud n(\%) & $4(19)$ & $1(11,1)$ & 0 & 0 & $1(20)$ \\
\hline Calcinosis $n(\%)$ & $1(4,5)$ & $1(11,1)$ & $(66,6)$ & 0 & 0 \\
\hline $\begin{array}{l}\text { Puffy hands } \\
\text { n (\%) }\end{array}$ & $2(9)$ & 0 & 0 & 0 & $2(40)$ \\
\hline Sicca synd $n(\%)$ & $3(13,6)$ & $1(11,1)$ & 0 & 0 & 0 \\
\hline Cáncer $n(\%)$ & $7(31,8)$ & $1(11,1)$ & 0 & 0 & 0 \\
\hline $\begin{array}{l}\text { Ck máx(UI/I), } \\
\text { median (IQR) }\end{array}$ & $432(171,706)$ & $809(350,1653)$ & - & - & $665(396,2300)$ \\
\hline
\end{tabular}

Conclusion: This register allows us to characterise patients with inflammatory myositis in our area. It is important to make multicentric and prospective registers in infrequent diseases such as IIM in order to have more detailed and representative information about clinical and socio-demographic characteristic as well as prognostic data from these patients.

References:

[1] Dalakas M. Inflammatory Muscle Diseasees. N Engl J Med 2015;372:1734-47. [2]Lündberg IE, Tjärnlund A, Bottai M, et al. 2017 Ann Rheum Dis2017;76:1955-1964.

[3] Betteridge Z, McHugh N. J. Intern Med, 2016 Jul;280(1):8-23.

[4] Nuño L et al. Reumatol Clin. 2017;13(6):331-337

[5] Lilleker JB, Vencovsky J, Wang G, et al.. Ann Rheum Dis 2018;77:30-39

Disclosure of Interests: None declared

DOI: 10.1136/annrheumdis-2020-eular.6125 